\title{
Water Quality Assessment of the Buriganga River, Dhaka, Bangladesh
}

\author{
Farhana Mustari* Sonia Afsana \\ Department of Environment; Ministry of Environment, Forest and Climate Change; Dhaka 1207, Bangladesh
}

\begin{abstract}
Bangladesh is situated in the lower part of the Ganges-Brahmaputra-Meghna (GBM) river basin, which is one of the most populated countries in the world. The Buriganga river system is located in the southern part of the northcentral region of the country, which passing through west and south of Dhaka, the capital of Bangladesh. A total of 96 water samples were collected from eight different points along the river and considered 10 physiochemical parameters such as Temperature, $\mathrm{pH}$, DO, BOD, COD, TDS, TSS, T. Alkalinity, EC, and Chloride during March 2015 to February 2016. Therefore, the study has investigated the status of the river water quality by above parameters and followed the Environmental Quality Standard (EQS) set in Bangladesh Environmental Conservation Rules (ECR, 1997), United States Environmental Protection Agency (USEPA) Water-Quality Standards (1994), and Bureau of Indian Standard (BIS, 1991). The mean values for the parameters in both dry and wet seasons were compared with the surface water quality standards measured by ECR. The result showed spatial and temporal variation of Temperature, $\mathrm{pH}, \mathrm{DO}, \mathrm{BOD}, \mathrm{COD}$, TDS, TSS, T. Alkalinity, EC, and Chloride from 21.4 to $30.0^{\circ} \mathrm{C}, 6.9$ to $7.9(\mathrm{mg} / \mathrm{L}), 0.0$ to $4.9(\mathrm{mg} / \mathrm{L}), 1$ to $23(\mathrm{mg} / \mathrm{L}), 8$ to $63(\mathrm{mg} / \mathrm{L}), 63$ to $566(\mathrm{mg} / \mathrm{L}), 16$ to 72 $(\mathrm{mg} / \mathrm{L}), 46$ to $295(\mathrm{mg} / \mathrm{L}), 138$ to $1133(\mu \mathrm{S} / \mathrm{cm})$, and 8 to $119(\mathrm{mg} / \mathrm{L})$ respectively. Where almost all the mean values from the samples were cross the standard limit. This study revealed that the water quality of Buriganga is not safe for aquatic life.
\end{abstract}

Keywords: Buriganga River, Water Quality, Pollution, Water Quality Parameters, Bangladesh Environmental Conservation Rules (ECR), Department of Environment (DoE), Bangladesh

DOI: $10.7176 /$ JEES/11-2-09

Publication date: February $28^{\text {th }} 2021$

\section{Introduction}

The Buriganga River "Old Ganges" flows past the southwest outskirts of Dhaka city. In the distant past, a course of the Padma river used to reach the Bay of Bengal through the Dhaleshwari river. This course gradually shifted and ultimately lost its link with the main channel of the Ganges and it was renamed the Buriganga (Majumdar, R. C., 1971, Khondker, K. 2012). This river is one of the most important rivers in Bangladesh. It is the lifeline of Dhaka city for irrigation, fisheries, transportation, recreational uses, and so on. Islam, M. M (2006) found that the river Buriganga is increasingly being polluted due to industrial flow and sewerage lines dumping huge volumes of toxic wastes all time. The uncontrolled release of sewage, industrial wastes, and agricultural run-off continue to affect many Asian countries, and the comprehensive national data of water quality indicates that the situation is serious for the future (Evans, A. E., et al 2012). The heavy metals concentration of Buriganga River is higher than the recommended value, where fish are not completely safe for health as well as aquatic life (Ahmad, M. K. et al 2010). The city of Dhaka discharges about 5,000 tons of solid waste every day and most of it is released into the Buriganga (F. A. Samiul Islam 2016). There are about 343 tannery industries and 627 dyeing industries are on the bank of Buriganga (Kamal, M. M., et al., 1999, and Ahmed, R. 2005). According to the Department of the Environment (DoE), 22,000 liters (5,800 US gal) of toxic waste are released into the river by the tanneries every day. According to an industrial survey of DoE (2014), almost 17,500 industries are located around greater Dhaka city. Industries like a tannery, steel plants, battery production, engineering, textile, dyeing, and washing are the prime polluters. In Dhaka, nearly one-third of domestic effluents do not receive any kind of treatment. About $38 \%$ of the population is covered by a sewerage system (Global Water Summit 2011). With the passages of time, tremendous human pressure on Buriganga river in terms of playing motorized water vessels, infrastructural development, encroachment, industrial and sewage waste dumping, etc. and dumping of ever-increasing all sorts of wastes turned Buriganga a worst polluted and ecologically dysfunctional river (Hossain, A. M. M., \& Rahman, S., 2011; Parvin, S et al., 2017). The Buriganga receives especially high amounts of food waste including rotting fruits, vegetables, and most alarming plastic can/container, poly bags are thrown into the river (DoE, 2014).

Being a vital component of an ecosystem, water is the most valuable resource for the sustenance of life and also for any development activity. The Department of Environment (DoE) under the Ministry of Environment and Forests has been monitoring surface water quality since 1973. DoE has 63 monitoring stations of 27 rivers in Bangladesh. DoE already declared the Buriganga River as an ecologically critical area (ECA). But the water quality of this river is undergoing continuous changes in terms of quality. The degradation of water quality is a result of rapid population growth, overplaying of motorized water vessels, uncontrolled development on the riverbanks, urbanization, unplanned industrialization, and agricultural operations. 
The present study was conducted to analyze some selected physiochemical water quality parameters like temperature, $\mathrm{pH}$, electrolytic conductivity (EC), dissolved oxygen (DO), chemical oxygen demand (COD), biochemical oxygen demand (BOD), total dissolved solids (TDS), suspended solids (SS), total alkalinity and chloride along the river.

\section{Methodology}

\subsection{Study Area}

The Buriganga River is $27 \mathrm{~km}$ long, its average width and depth are 400 and $10 \mathrm{~m}$ respectively and also catchment area is $253 \mathrm{~km} 2$ (Saiful Islam, et al, 2015). Due to the proximity to suspected pollution sources and the ecological, environmental and aesthetic importance, samples were collected from eight different locations (Mirpur Bridge, Hazaribag, Kamrangir Char, Chandni Ghat, Sadar Ghat, Dholaikhal, Bangladesh China Friendship Bridge-BCFB, and Pagla) along the river for water quality monitoring (figure 1).

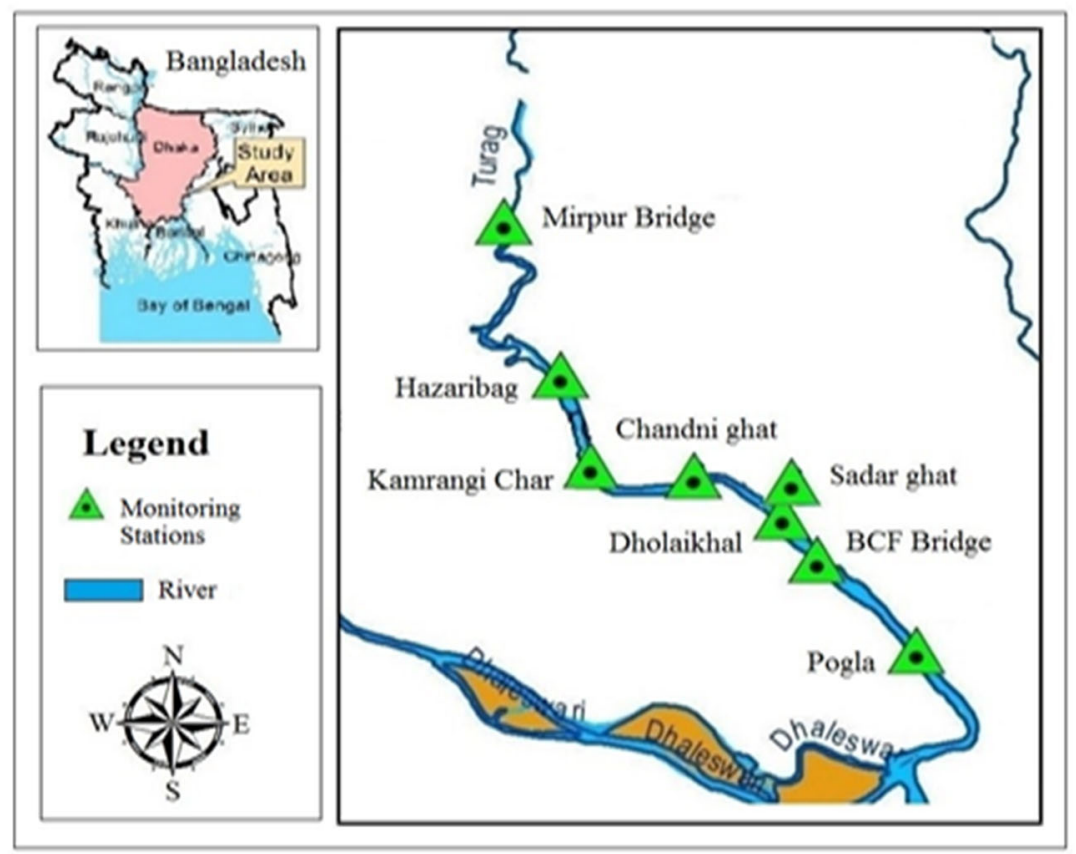

Figure 1. Location Map of the Study Area

\subsection{Sample collection and measurement of different parameters}

A total of 96 water samples were collected from March 2015 to February 2016 to observe the seasonal variations of the water quality of the river. Samples were collected by each 1 litre Polypropylene bottles and each $300 \mathrm{~mL}$ Winkler bottles. Before collecting the samples, sampling bottles were cleaned properly with a dilute chromic acid solution followed by de-ionized water. All samples were grab samples and taken from pre-designated locations. Samples were collected at a depth of 1 meter. The temperature was measured on-site. The sampling bottles were immediately labelled, preserved, and conveyed to the laboratory for other tests. Samples were analyzed at the Dhaka Laboratory of DoE. All water quality parameters were tested as per Standard Methods for Water \& Wastewater of the American Public Health Association (APHA). The temperature was measured with degree Celsius $\left({ }^{\circ} \mathrm{C}\right)$ by the thermometer, $\mathrm{pH}$ was measured using HANNA HI 2211 benchtop pH meter by potentiometric method, Electrolytic Conductivity (EC) using HANNA HI 2030 benchtop meter. Total Dissolve Solid (TDS), Suspended Solids (SS) measurement was conducted by gravimetric method; Dissolve Oxygen (DO) was measured using azide modification of Winkler method, open refluxed followed by the colorimetric method was used to measure Chemical Oxygen Demand (COD), 5-day Biochemical Oxygen Demand (BOD) was measured by dilution method followed by azide modification of Winkler method, argentrometric method was used to measure Chloride and the titrimetric method was used to measure Total Alkalinity. HACH digital reactor block and HACH spectrophotometer DR2700 were used for COD measurement. The water quality parameter and measurement methods are shown in table 1. 
Table 1. Water Quality parameter and measurement methods

\begin{tabular}{|l|l|l|l|l|}
\hline No & Parameter & Unit & Methods & Measurement Site \\
\hline \multicolumn{5}{|l|}{ Physical } \\
\hline 1 & Temperature & ${ }^{0} \mathrm{C}$ & Thermometer & In situ \\
\hline 2 & TSS & $\mathrm{mg} / \mathrm{L}$ & Gravimetric & Laboratory \\
\hline 3 & TDS & $\mathrm{mg} / \mathrm{L}$ & Gravimetric & Laboratory \\
\hline 4 & EC & $\mu \mathrm{S} / \mathrm{m}$ & Potentometric & Laboratory \\
\hline Chemical & - & Potentometric & Laboratory \\
\hline 5 & pH & $\mathrm{mg} / \mathrm{L}$ & Winkler azide modification & Laboratory \\
\hline 6 & DO & $\mathrm{mg} / \mathrm{L}$ & Winkler and dilution & Laboratory \\
\hline 7 & BOD & $\mathrm{mg} / \mathrm{L}$ & closed reflux colorimetric & Laboratory \\
\hline 8 & COD & $\mathrm{mg} / \mathrm{L}$ & titrimetric & Laboratory \\
\hline 9 & Total Alkalinity & $\mathrm{mg} / \mathrm{L}$ & argentrometric & Laboratory \\
\hline 10 & Chloride &
\end{tabular}

\section{Results and Discussions}

The result obtained on the physicochemical parameters is presented in table 2. According to ECR, 1997, Bangladesh, for river/surface water quality there is a standard only for DO, BOD, and $\mathrm{pH}$ parameters. For this reason, the different river/surface water quality parameters are compared with Water-Quality Standards (the United States Environmental Protection Agency-USEPA, 1986), United Nations Economic Commission for EuropeUNECE standard statistical classification of surface freshwater quality for the maintenance of aquatic life as well as Indian national tolerance limits for inland surface waters used for fish culture and wildlife propagation as per BIS 2296:1982 along with Bangladesh inland surface water quality standards for fisheries and irrigation as per ECR, 1997.

Table 2 Results of different Water Quality parameter of the Buriganga River

\begin{tabular}{|c|c|c|c|c|c|c|c|c|c|c|c|}
\hline \multirow[t]{2}{*}{$\begin{array}{l}\text { Month/Year } \\
\text { Unit }\end{array}$} & Data & Temperature & $\mathrm{pH}$ & $\mathrm{EC}$ & Chloride & $\begin{array}{l}\text { Total } \\
\text { Alkalinity }\end{array}$ & TDS & TSS & DO & BOD & COD \\
\hline & & ${ }^{0} \mathrm{C}$ & - & $(\mu \mathrm{S} / \mathrm{cm})$ & $\mathrm{mg} / \mathrm{L}$ & $\mathrm{mg} / \mathrm{L}$ & $\mathrm{mg} / \mathrm{L}$ & $\mathrm{mg} / \mathrm{L}$ & $\mathrm{mg} / \mathrm{L}$ & $\mathrm{mg} / \mathrm{L}$ & $\mathrm{mg} / \mathrm{L}$ \\
\hline \multirow{3}{*}{ March 2015} & Mean & 21.0 & 7.52 & 1130 & 119 & 295 & 566 & 72 & 0.0 & 21 & 59 \\
\hline & $\operatorname{Max}^{\mathrm{m}}$ & 23.0 & 7.72 & 1238 & 135 & 344 & 639 & 100 & 0.0 & 26 & 81 \\
\hline & $\operatorname{Min}^{\mathrm{m}}$ & 19.0 & 7.41 & 1068 & 108 & 244 & 533 & 55 & 0.0 & 13 & 46 \\
\hline \multirow{3}{*}{ April 2015} & Mean & 30.0 & 7.62 & 1133 & 37 & 149 & 553 & 51 & 0.0 & 23 & 63 \\
\hline & $\operatorname{Max}^{\mathrm{m}}$ & 30.0 & 7.71 & 1174 & 42 & 180 & 578 & 80 & 0.0 & 35 & 70 \\
\hline & $\operatorname{Min}^{\mathrm{m}}$ & 29.0 & 7.45 & 1070 & 31 & 110 & 522 & 40 & 0.0 & 12 & 40 \\
\hline \multirow{3}{*}{ May 2015} & Mean & 25.5 & 7.09 & 613 & 58 & 184 & 294 & 59 & 0.5 & 12 & 38 \\
\hline & $\operatorname{Max}^{\mathrm{m}}$ & 25.0 & 7.16 & 719 & 68 & 226 & 347 & 63 & 2.5 & 17 & 55 \\
\hline & $\operatorname{Min}^{\mathrm{m}}$ & 25.0 & 6.93 & 419 & 36 & 108 & 198 & 46 & 0.0 & 6 & 17 \\
\hline \multirow{3}{*}{ June 2015} & Mean & 29.9 & 7.41 & 202 & 11 & 52 & 88 & 34 & 1.6 & 7 & 8 \\
\hline & $\operatorname{Max}^{\mathrm{m}}$ & 30.0 & 7.53 & 224 & 12 & 58 & 97 & 38 & 2.3 & 12 & 62 \\
\hline & $\operatorname{Min}^{\mathrm{m}}$ & 29.0 & 7.21 & 191 & 9 & 48 & 83 & 29 & 0.8 & 1 & 4 \\
\hline \multirow{3}{*}{ July 2015} & Mean & 29.1 & 6.91 & 138 & 8 & 46 & 63 & 26 & 4.9 & 1 & 15 \\
\hline & $\operatorname{Max}^{\mathrm{m}}$ & 29.0 & 7.16 & 142 & 9 & 50 & 65 & 35 & 5.7 & 2 & 31 \\
\hline & $\operatorname{Min}^{\mathrm{m}}$ & 28.0 & 6.58 & 133 & 6 & 40 & 60 & 18 & 4.2 & 1 & 4 \\
\hline \multirow{3}{*}{ August 2015} & Mean & 28.3 & 7.13 & 147 & 8 & 50 & 64 & 26 & 4.7 & 4 & 15 \\
\hline & $\operatorname{Max}^{\mathrm{m}}$ & 28.0 & 7.18 & 160 & 9 & 54 & 70 & 34 & 5.6 & 5 & 18 \\
\hline & $\operatorname{Min}^{\mathrm{m}}$ & 28.0 & 7.02 & 125 & 6 & 47 & 54 & 18 & 3.8 & 3 & 7 \\
\hline \multirow{3}{*}{ September 2015} & Mean & 29.6 & 6.92 & 155 & 8 & 53 & 66 & 16 & 3.7 & 8 & 26 \\
\hline & $\operatorname{Max}^{\mathrm{m}}$ & 29.0 & 7.02 & 165 & 10 & 59 & 71 & 18 & 4.6 & 11 & 28 \\
\hline & $\operatorname{Min}^{\mathrm{m}}$ & 29.0 & 6.58 & 150 & 6 & 48 & 59 & 12 & 2.4 & 5 & 15 \\
\hline \multirow{3}{*}{ October 2015} & Mean & 29.3 & 6.91 & 230 & 14 & 55 & 99 & 44 & 2.5 & 13 & 43 \\
\hline & $\operatorname{Max}^{\mathrm{m}}$ & 29.0 & 6.99 & 255 & 19 & 58 & 110 & 50 & 4.5 & 24 & 78 \\
\hline & $\operatorname{Min}^{\mathrm{m}}$ & 29.0 & 6.88 & 201 & 12 & 48 & 86 & 40 & 1.4 & 6 & 25 \\
\hline \multirow{3}{*}{ November 2015} & Mean & 23.7 & 7.86 & 322 & 28 & 54 & 167 & 17 & 0.7 & 13 & 48 \\
\hline & $\operatorname{Max}^{\mathrm{m}}$ & 24.0 & 7.98 & 344 & 31 & 60 & 177 & 22 & 2.4 & 25 & 79 \\
\hline & $\operatorname{Min}^{\mathrm{m}}$ & 23.0 & 7.74 & 310 & 25 & 50 & 155 & 12 & 0.1 & 7 & 22 \\
\hline \multirow{3}{*}{ December 2015} & Mean & 21.4 & 7.28 & 753 & 66 & 158 & 394 & 34 & 0.2 & 13 & 49 \\
\hline & $\operatorname{Max}^{\mathrm{m}}$ & 21.0 & 7.40 & 811 & 76 & 178 & 424 & 61 & 1.3 & 35 & 124 \\
\hline & $\operatorname{Min}^{\mathrm{m}}$ & 21.0 & 7.02 & 673 & 47 & 140 & 349 & 22 & 0.0 & 6 & 24 \\
\hline \multirow{3}{*}{ January 2016} & Mean & 20.0 & 7.50 & 739 & 49 & 147 & 374 & 37 & 0.0 & 11 & 30 \\
\hline & $\operatorname{Max}^{\mathrm{m}}$ & 21.0 & 7.58 & 750 & 53 & 154 & 384 & 42 & 0.0 & 16 & 42 \\
\hline & $\operatorname{Min}^{\mathrm{m}}$ & 19.0 & 7.42 & 712 & 45 & 142 & 364 & 32 & 0.0 & 5 & 12 \\
\hline \multirow{3}{*}{ February 2016} & Mean & 19.5 & 7.33 & 1124 & 52 & 106 & 559 & 23 & 0.0 & 29 & 86 \\
\hline & $\operatorname{Max}^{\mathrm{m}}$ & 19.8 & 7.44 & 1182 & 57 & 213 & 586 & 32 & 0.0 & 50 & 212 \\
\hline & $\operatorname{Min}^{\mathrm{m}}$ & 19.3 & 7.04 & 1096 & 47 & 57 & 550 & 14 & 0.0 & 18 & 57 \\
\hline
\end{tabular}




\begin{tabular}{|c|c|c|c|c|c|c|c|c|c|c|}
\hline \multirow[t]{2}{*}{$\begin{array}{l}\text { Month/Year } \\
\text { Unit }\end{array}$} & Temperature & $\mathrm{pH}$ & $\mathrm{EC}$ & Chloride & $\begin{array}{l}\text { Total } \\
\text { Alkalinity }\end{array}$ & TDS & TSS & $\mathrm{DO}$ & BOD & COD \\
\hline & ${ }^{0} \mathrm{C}$ & - & $(\mu \mathrm{S} / \mathrm{cm})$ & $\mathrm{mg} / \mathrm{L}$ & $\mathrm{mg} / \mathrm{L}$ & $\mathrm{mg} / \mathrm{L}$ & $\mathrm{mg} / \mathrm{L}$ & $\mathrm{mg} / \mathrm{L}$ & $\mathrm{mg} / \mathrm{L}$ & $\mathrm{mg} / \mathrm{L}$ \\
\hline $\begin{array}{l}\text { BDWQS according to ECR } \\
1997 \text { Water usable by fisheries }\end{array}$ & - & $\begin{array}{l}6.5 \\
- \\
8.5\end{array}$ & - & - & - & - & - & $\begin{array}{l}5 \text { or } \\
\text { more }\end{array}$ & $\begin{array}{l}6 \text { or } \\
\text { less }\end{array}$ & - \\
\hline $\begin{array}{l}\text { BDWQS according to ECR } \\
1997 \text { Water usable for } \\
\text { irrigation }\end{array}$ & - & $\begin{array}{l}6.5 \\
- \\
8.5 \\
\end{array}$ & 2250 & - & - & - & - & $\begin{array}{l}5 \text { or } \\
\text { more }\end{array}$ & $\begin{array}{l}10 \text { or } \\
\text { less }\end{array}$ & - \\
\hline $\begin{array}{lcl}\text { USEPA } & \text { Water- } & \text { Quality } \\
\text { Standards } & (1994 a) & \end{array}$ & $20-31$ & $\begin{array}{l}6.5- \\
8.5\end{array}$ & - & 250 & - & 500 & 25 & $\begin{array}{l}4 \text { or } \\
\text { more }\end{array}$ & - & - \\
\hline $\begin{array}{l}\text { UNECE standard statistical } \\
\text { classification of surface } \\
\text { freshwater quality for the } \\
\text { maintenance of aquatic life }\end{array}$ & - & $\begin{array}{l}6.5- \\
9.0\end{array}$ & & & $\begin{array}{l}200 \text { or } \\
\text { more }\end{array}$ & - & - & $\begin{array}{l}7 \text { or } \\
\text { more }\end{array}$ & - & $\begin{array}{l}3 \text { or } \\
\text { less }\end{array}$ \\
\hline $\begin{array}{l}\text { Indian national tolerance limits } \\
\text { for inland surface waters used } \\
\text { for fish culture and wild life } \\
\text { propagation as per BIS } \\
2296: 1982\end{array}$ & - & $\begin{array}{l}6.8- \\
8.5\end{array}$ & 1000 & - & - & - & - & $\begin{array}{l}4 \text { or } \\
\text { more }\end{array}$ & - & - \\
\hline
\end{tabular}

\subsection{Temperature}

The mean value of the temperature of all collected samples was within the range of $19^{\circ} \mathrm{C}$ to $30^{\circ} \mathrm{C}$ (figure 2 (a)) . The minimum temperature was found at $19^{\circ} \mathrm{C}$ at the Chadnighat point in March. According to the observed values, the temperature of the Buriganga River is within the range of USEPA Water- Quality Standards (USEPA, 1986). During the dry season in winter, the temperature of the river remains below the acceptable level at 1-2 points.

\section{$3.2 \mathrm{pH}$ and Total Alkalinity}

$\mathrm{pH}$ expresses the acidic or alkaline nature of water, thus it determines the corrosive condition of the water. $\mathrm{pH}$ greatly affects the biological activity in the river. The mean values for all the sampling stations were found within the limit of BDEQS, USEPA, UNECE, and Indian standards. The $\mathrm{pH}$ range of The Buriganga river is 6.88 to 7.98 (figure 2(b)). The maximum $\mathrm{pH}$ was found at 7.98 at Mirpur Bridge in November. Thus, the river can be characterized as neutral from an acidic or alkalinity point of view. Measuring alkalinity is important in determining a river's ability to neutralize acidic pollution from rainfall or wastewater. Research studies have shown that there is a relationship between $\mathrm{pH}$ and total alkalinity present in water. In general, when alkalinity increases, the $\mathrm{pH}$ tends to be higher. In March and April where the $\mathrm{pH}$ value of the river is relatively high to that of other months of that year, the value of total alkalinity is comparatively higher. The Total Alkalinity results show the sensitivity of the stream to acid inputs. The mean Total Alkalinity of all collected samples of Buriganga was varied from 46mg/L to $344 \mathrm{mg} / \mathrm{L}$. According to the UNECE standard the tolerance limit is $200 \mathrm{mg} / \mathrm{L}$, these results are within the limit in March and April but didn't meet the limit in the following months. The highest value of total alkalinity was 295 $\mathrm{mg} / \mathrm{L}$ at Chadnighat in March (figure 2(c)).

\subsection{Dissolved Oxygen (DO)}

Dissolved Oxygen (DO) value has been found higher in the wet season compared to the dry season. The lowest value of DO was $0.0 \mathrm{mg} / \mathrm{L}$ in all points of the dry season (March, April, January \& February) and the highest of that is $4.9 \mathrm{mg} / \mathrm{L}$ at Sadarghat point in July (figure 2(d)). The measured values of DO and with its maximum value never reached the acceptable level (EQS is $5 \mathrm{mg} / \mathrm{L}$ or more according to ECR) in any of the sampling stations. As $\mathrm{DO}$ is a vital water quality parameter for most chemical and biological processes in the water column and essential for aquatic life, no life can survive in the Buriganga river with such a low DO value. The river nearly reaches a dying stage. 

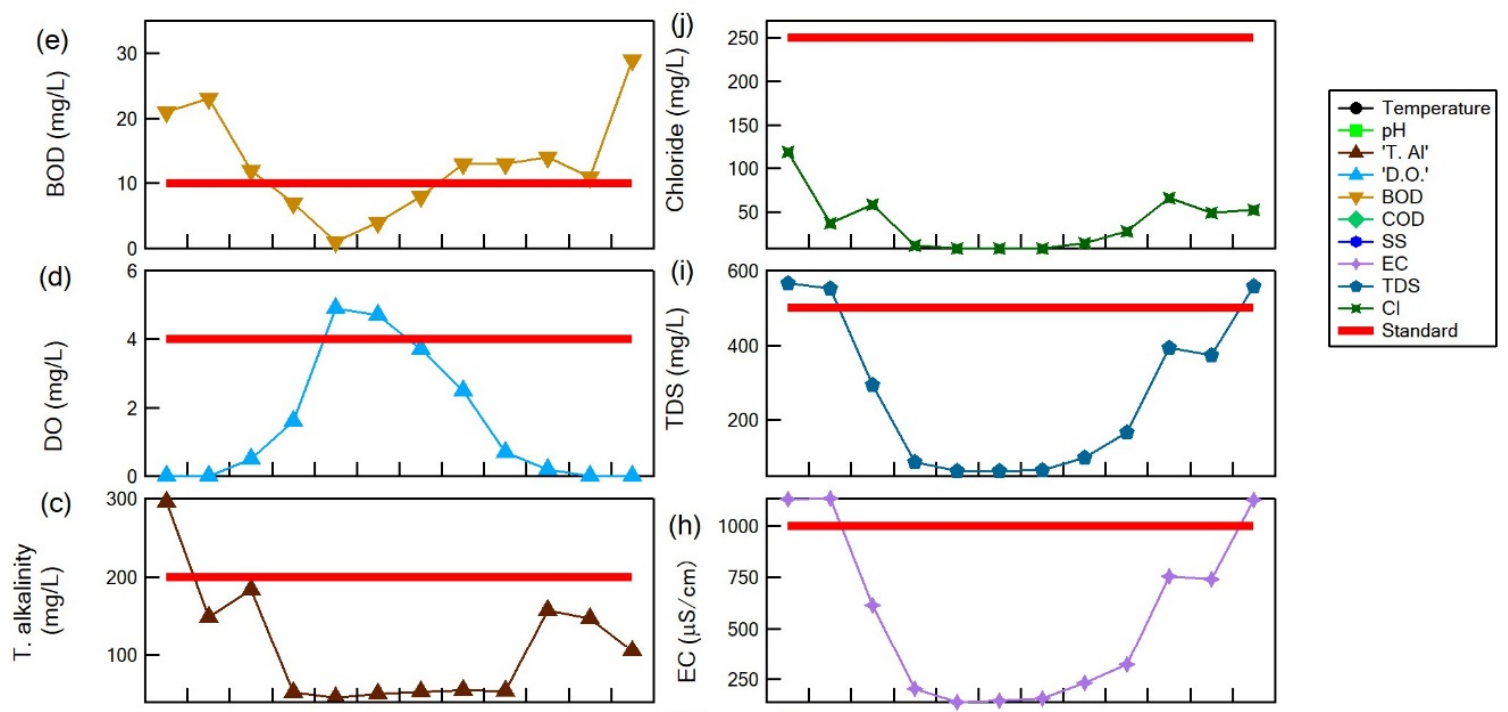

(b)
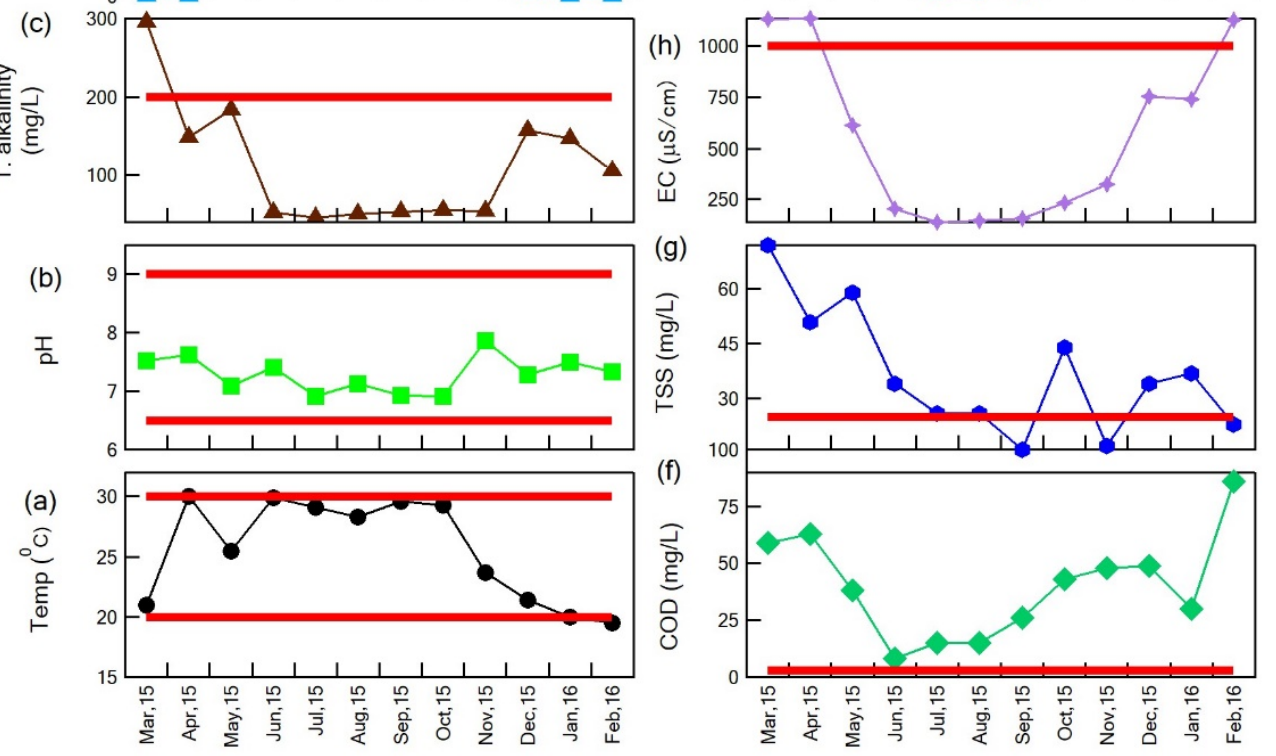

Month

Figure 2. Mean (a) Temperature, (b) pH, (c) Total alkalinity, (d) Dissolved oxygen (DO), (e) Biochemical oxygen demand (BOD), (f) Chemical oxygen demand (COD), (g) Total suspended solid (TSS), (h) Electrolytic conductivity (EC), (i) Total dissolved solid (TDS) and (j) Chloride values of the study area from March 2015 to February 2016

\subsection{Biochemical Oxygen Demand (BOD)}

The Biochemical Oxygen Demand (BOD) of the Buriganga river was found higher in the dry season compared to the wet season. Among the eight points, the highest BOD is $50 \mathrm{mg} / \mathrm{L}$ at Bangladesh China Friendship Bridge point in February and the lowest is $1.0 \mathrm{mg} / \mathrm{L}$ at Chadnighat in July (figure 2(e)). BOD meets the acceptable limits for fisheries which are $6 \mathrm{mg} / \mathrm{L}$ or less (according to ECR) only in July and August i.e., in the wet season. The higher BOD of the river is the result of pollution with various organic pollutants. The high value of BOD also indicates the presence of excessive amounts of microorganisms in the water, which consumes the oxygen levels in the river.

\subsection{Chemical Oxygen Demand (COD)}

Chemical Oxygen Demand (COD) is also an important parameter for river water quality assessment. This measures the total quantity of oxygen required to oxidize all organic material and the oxidation of inorganic chemicals such as ammonia and nitrite into carbon dioxide and water. COD indirectly measures the number of organic compounds in water. The higher COD values indicate the presence of higher organic materials in the river. Unlike BOD, COD values were found higher in the dry season compared to the wet season. The lowest value of COD was $4 \mathrm{mg} / \mathrm{L}$ at Chadnighat in July and the highest was $212 \mathrm{mg} / \mathrm{L}$ at Sadar Ghat in February (figure 2(f)). COD value is far away from its acceptance limit of $3 \mathrm{mg} / \mathrm{L}$ or less according to the UNECE standard.

\subsection{Total Suspended Solid (TSS)}

The Total Suspended Solid (TSS) value range in the Buriganga river is $100 \mathrm{mg} / \mathrm{L}$ to $12 \mathrm{mg} / \mathrm{L}$. The acceptance limit of TSS is $25 \mathrm{mg} / \mathrm{L}$ according to USEPA standard. The highest value of TSS was $100 \mathrm{mg} / \mathrm{L}$ at Pagla in March (figure $2(\mathrm{~g})$ ). Thus, the results show that the TSS values are high in the dry season but low in the wet season. TSS 
increases the turbidity of water. The TSS value may include a wide variety of materials, such as silt, decaying plant, and animal matter. If there are of biological origin, they would increase the BOD. The high concentration of TSS does not allow the light to penetrate the water which is detrimental to submerged vegetation. This reduces the rate of photosynthesis and a lesser amount of dissolved oxygen will release into the water. In extreme conditions, the submerged vegetation dies due to the unavailability of light. The dead vegetation will decompose by bacteria that will utilize more oxygen thereby creating a condition of suffocation detrimental to aquatic fauna. High TSS can also increase surface water temperature as suspended particles absorb more heat. Generally, the TSS concentration is relatively high during a high hydraulic load.

\subsection{Electrolytic Conductivity (EC)}

The Electrolytic Conductivity (EC) value of all collected samples was within the range of $125 \mu \mathrm{S} / \mathrm{cm}$ to $1238 \mu \mathrm{S} / \mathrm{cm}$ (figure 2(h)). According to the observed values, the EC of the Buriganga River is within the range of USEPA Water- Quality Standards (1994a). The highest value of EC was $1238 \mu \mathrm{S} / \mathrm{cm}$ at Mirpur Bridge in March. From the results; it is found that the $\mathrm{EC}$ of the river remains above the acceptable level during the dry season. In the dry season, the flow of the river decreases which increases EC.

\subsection{Total Dissolved Solid (TDS)}

The Total Dissolved Solid (TDS) values of Buriganga River were also found higher in the dry season compared to the wet season. The TDS value of all collected samples was within the range of 60 to $639 \mathrm{mg} / \mathrm{L}$ (figure 2(i)). These values were higher than the acceptance limit of $500 \mathrm{mg} / \mathrm{L}$ as per the USEPA standard in March and April. The highest value of TDS was $639 \mathrm{mg} / \mathrm{L}$ at Mirpur Bridge in March. TDS mainly indicates the presence of various kinds of minerals like ammonia, nitrite, nitrate, phosphate, alkalis, some acids, sulfates, and metallic ions, etc which are comprised of both colloidal and dissolved solids in water. It is also an important chemical parameter of water. From the result, it is also observed that the EC value increased with the increasing value of TDS.

\section{Conclusion}

In recent years the Buriganga river has become a dumping ground of all kinds of solid-liquid and chemical wastes that are generated by the activities in and around the river. The present study shows that the river water is still acceptable in terms of parameters such as temperature, $\mathrm{pH}$, chloride, EC, TDS but the parameters like DO, BOD, COD, TSS indicate that the water quality of the Buriganga river is unfavorable for all aquatic lives and human being. The study also reveals that the river water quality showed a seasonal variation. During the dry season with a lower water flow almost all the parameters exceed the standard compared to the wet season. On the other hand, during the rainy season pollution load is diluted by the higher water. Therefore, river pollution is also largely dependent on the upstream river flow. In Bangladesh, there are 57 trans-boundary rivers and the river water quality is also dependent on the flow of upstream trans-boundary rivers. Effective mitigation measures should be taken to reduce the level of pollution for the restoration of ecologically critical areas like the Buriganga river.

\section{Acknowledgments}

We are grateful to the Department of Environment (DoE) under the Ministry of Environment, Forest and Climate Change (MoEFCC) for the support from the Dhaka Laboratory. Mr. Md Mahbubur Rahman Khan, Research Officer, DoE for the valuable review comments on the first draft.

\section{References}

Ahmad, M. K., Islam, S., Rahman, M. S., Haque, M. R., \& Islam, M. M. (2010). "Heavy metals in water, sediment, and some fishes of Buriganga River, Bangladesh", International Journal of Environmental Research, 4(2), 321-332.

Ahmed, R. (2005). "Existing Environmental Status of Hazaribagh, Dhaka". Training Institute for Chemical Industries, Narsingdi.

DoE (2014) "River Water Quality Report, Department of Environment (DoE)", Ministry of Environment and Forests, Published 2015, ISSN 2226-1575

Evans, A. E., Hanjra, M. A., Jiang, Y., Qadir, M., \& Drechsel, P. (2012). "Water quality: assessment of the current situation in Asia", International Journal of Water Resources Development, 28(2), 195-216.

F. A. Samiul Islam (2016). "Solid Waste Management System in Dhaka City of Bangladesh", Journal of Modern Science and Technology, Vol. 4. No. 1. Pp. $192-209$

Hossain, A. M. M., \& Rahman, S. (2011). "Hydrography of Dhaka city catchment and the impact of urbanization on water flows a review". Asian Journal of Water, Environment and Pollution, 8(4), 27-36.

"Industrial Survey Report on Dhaka Division (2014)", Department of Environment (DoE), Ministry of Environment, and Forests.

Islam, M. M., Akhtar, M. K., \& Masud, M. S. (2006, May). "Prediction of environmental flow to improve the 
water quality in the river Buriganga". In Proceedings of the 17th IASTED international conference on modeling and simulation, Montreal, QC, Canada.

Jackson, S., \& Davis, W. (1994). "Meeting the goal of biological integrity in water-resource programs in the US Environmental Protection Agency”. Journal of the North American Benthological Society, 13(4), 592-597.

Kamal, M. M., Malmgren-Hansen, A., \& Badruzzaman, A. B. M. (1999). "Assessment of pollution of the River Buriganga, Bangladesh, using a water quality model”, Water science and technology, 40(2), 129-136.

Khondker, K. (2012). "Mughal river forts in Bangladesh (1575-1688): An archaeological appraisal” (Doctoral dissertation, Cardiff University).

Majumdar, R. C. (1971). "History of ancient Bengal”. Calcutta: G. Bharadwaj.

Parvin, S., Mazumder, L. T., Hasan, S., Rabbani, K. A., \& Rahman, M. L. (2017). "What should we do with our solid tannery waste?” IOSR J Environ Sci Toxicol Food Technol, 11(4), 82-89.

Saiful Islam, M. Khabir Uddin, Shafi M. Tareq, Mashura Shammi, Abdul Kadir Ibne Kamal, Tomohiro Sugano, Masaaki Kurasaki, Takeshi Saito, Shunitz Tanaka and Hideki Kuramitz (2015). "Alteration of Water Pollution Level with the Seasonal Changes in Mean Daily Discharge in Three Main Rivers around Dhaka City, Bangladesh", Environments, 2, 280-294; doi:10.3390/environments2030280

“Survey of Industries around Dhaka City", Department of Environment (2013).

Taqsem Khan: "The performance challenges of Dhaka WASA, in Global Water Intelligence: Focusing on performance", Global Water Summit 2011, p. 50-52.

USEPA (1986) the United States Environmental Protection Agency Ambient Water Quality Criteria for Bacteria1986. EPA440/ 5-84-002.

First Author: 1. Farhana Mustari: Born in 1984 at Chandpur district in Bangladesh. Completed MSc in Biochemistry and Molecular Biology from the Jahangirnagar University, Bangladesh. At present working as a Deputy Director at the Department of Environment under the Ministry of Environment, Forest and Climate Change, Bangladesh.

2. Sonia Afsana: Born in 1985 at Dhaka in Bangladesh. Completed MSc in Chemistry from the Dhaka University; Senior Chemist at the Department of Environment under the Ministry of Environment, Forest and Climate Change, Bangladesh, and now she is working (deputation) as a Ph.D. student at the Nagoya University, Japan. 